\title{
TEN-YEARS LATER: LONG-TERM ANALYSES OF THE ABUNDANCE AND BIOMASS OF THE NON-NATIVE NEW ZEALAND MUD SNAIL AND NATIVE INVERTEBRATE COMMUNITIES IN THE GREATER YELLOWSTONE AREA
}

\author{
TERESA TIBBETS $\uparrow$ UNIVERSITY OF WYOMING $\bullet$ LARAMIE
}

\begin{abstract}
$\uparrow$ ABSTRACT
Invasive species are one of the top two threats to native biodiversity worldwide (Mack et al. 2000). A primary goal of invasion biology is to predict which introduced species become invasive, or reach pest status, and which systems are susceptible to invasion (Heger and Trepl 2003). In order to complete this goal, it is vital to understand long-term dynamics of invasive species populations and their interactions with native communities in their introduced range. Most studies of invasions by nonnative species are not extensive enough to determine long-term effects on the native systems (Strayer 2010). The first objective of this study is to determine the long-term abundance and biomass of the New Zealand mud snail, (Potamopyrgus antipodarum), in the Greater Yellowstone Area (GYA). The second objective is to analyze the long-term effects of $P$. antipodarum on the biomass, abundance, and taxon diversity of native benthic invertebrate assemblages in the GYA. The ten-year span of data available for $P$. antipodarum and the native macroinvertebrate communities at Lower Polecat Creek in Grand Teton National Park and the Gibbon and Firehole Rivers in Yellowstone National Park provide a unique opportunity to study the macroinvertebrate community succession over time. Data from the proposed macroinvertebrate community survey in the summer of 2011 will be compiled with previous surveys from 2001-2009 to evaluate the long-term changes in the macroinvertebrate community at Polecat Creek and the Gibbon and Firehole Rivers.
\end{abstract}

\section{$\uparrow \quad$ INTRODUCTION}

The New Zealand mud snail (Potamopyrgus antipodarum), a herbivorous gastropod native to New Zealand, has spread throughout Europe, Australia, and North America (Zaranko et al. 1997), frequently reaching pest densities. P. antipodarum is currently found in all western states in the United States except for New Mexico and is predicted to continue expansion into the Midwest states to the east coast (Loo et al. 2007). Introduced populations of $P$. antipodarum in Europe and North America are made up of 3 genetic clones of parthenogenic, ovoviviparous females (Dybdahl and Kane 2005) that can rapidly produce large populations in introduced freshwater habitats (Schreiber et al. 2003, Hall et al. 2006). While prevention of its initial invasion is a major management goal, there is still a question about how ecosystems that are already invaded will be affected in the long-term. There has been a recent increase in criticism that most studies of invasions by non-native species are not extensive enough to determine long-term effects on the native systems (Strayer 2010). There is much to be learned by following the ecological effects of non-native species over time since we know very little about long-term changes at the population, community, and ecosystem levels. Therefore, there is an urgent need to understand the long-term outcome in systems where introduction has already occurred.

Since $P$. antipodarum was first detected in the Greater Yellowstone Area in 1994, it has since spread across the region, reaching high densities in 
stable, geothermally influenced rivers in the area (Kerans et al. 2005, Hall et al. 2006). High rates of growth and secondary production have been documented for $P$. antipodarum in its introduced range in the GYA (Hall et al. 2003, Kerans et al. 2005, Hall et al. 2006), as have evidence of negative interactions between $P$. antipodarum and native macroinvertebrates (Kerans et al. 2005, Riley et al. 2008). Another example of the potential effect of high $P$. antipodarum biomass is its control of ecosystem-scale fluxes of carbon and nitrogen, as observed in Polecat Creek (Hall et al. 2003).

Results from Hall et al. (2003 and 2006) indicate that $P$. antipodarum can achieve high densities in rivers within the GYA and have a large effect on primary productivity and other ecosystem processes. Recent studies indicate at least five groups of native macroinvertebrates are affected by $P$. antipodarum. In experimental conditions, two species of native snails, Pyrgulopsis robusta (like $P$. antipodarum, a member of the Hydrobiidae), and Fossaria sp. (Lymnaeidae) exhibit reduced growth in the presence of $P$. antipodarum (Riley et al. 2008). Inter-specifc competition is also suggested by negative associations between the density of $P$. antipodarum and several families of insects in a river basin of the GYA (Kerans et al. 2005).

However, $P$. antipodarum has not reached uniformly high densities through its new range in the GYA (personal observation, Kerans et al. 2005). In addition, observations over the past few years indicate a potential decline in the abundance of $P$. antipodarum in Lower Polecat Creek (A. Krist and T. Tibbets personal communication). During field work in July 2007 and 2008, many thousands of individuals of $P$. antipodarum could be collected in an hour at Polecat Creek. Currently, the same effort yields a few hundred at most. Does this observation indicate a real decline in mud snail population? Is this decline unique to Polecat Creek, or at a regional scale? I intend to answer these questions within rivers of the GYA. My first objective is to determine if changes have occurred in the abundance and biomass of $P$. antipodarum during the past ten years in rivers of the GYA. The second objective is to analyze the long-term effects of $P$. antipodarum on the biomass, abundance, and taxon diversity of native benthic invertebrate assemblages.

\section{STUDY AREA}

The first sample site is located in Lower Polecat Creek approximately $300 \mathrm{~km}$ upstream of Huckleberry Hot Springs outlet in the John D.
Rockefeller National Parkway, within the permit jurisdiction of Grand Teton National Park (UTM 12 $525010 \mathrm{E}, 4883960 \mathrm{~N})$. The two study sites in Yellowstone National Park are the Gibbon River and Firehole River. The sample site on the Gibbon River is approximately $200 \mathrm{~m}$ upstream from the bridge at Madison Junction (UTM 12 511173E, 4943166N). The sample site for the Firehole River is approximately $100-300 \mathrm{~m}$ downstream of the Fountain freight bridge near Ojo Caliente spring at the downstream end of Geyser Basin. The specific study sites were chosen based on sites used in Hall et al. 2006.

\section{$\uparrow \quad$ METHODS}

Benthic invertebrate biomass and abundance was quantified for three sampling dates in the months of June, July, and September 2011 in Lower Polecat Creek. The Gibbon and Firehole Rivers were sampled in late September 2011. I used methods from previous sampling efforts identical to those described in Hall et al. 2003 and 2006.

Each month, six quantitative samples of benthic invertebrates were collected using a $15.2 \mathrm{~cm}$ diameter stovepipe corer (Figure 1). For each sample, fine sediments $(<5 \mathrm{~cm})$ and macrophytes were removed before samples were elutriated and collected on a $250 \mu \mathrm{m}$ sieve or Hess sampler. All biomass from primary producers was sorted and analyzed for ashfree dry mass. Subsamples of tissue from primary producers will be analyzed for Carbon and Nitrogen elemental composition using a Carlo-Erba CN analyzer at the University of Wyoming Stable Isotope Laboratory. Each macroinvertebrate sample was preserved in $95 \%$ ethanol immediately. Samples were stained with Phloxine B and sorted in the laboratory into $250 \mu \mathrm{m}-1 \mu \mathrm{m}$ and $>1 \mu \mathrm{m}$ size classes before identification to genus. I estimated invertebrate biomass by measuring the length of each individual and using published length-mass regressions to estimate ash-free dry mass for each taxon (see Benke et al. 1999, Hall et al. 2006).

Robert Hall (University of Wyoming) and Mark Dybdahl (Washington State University) have agreed to share published and unpublished data from 2000-2001 with me for the purpose of this historical study. Amy Krist and Heather Thon (University of Wyoming) will contribute invertebrate data from 2007 and 2009. The collaborators noted above will be co-authors on any publications resulting from these analyses. I will use the long-term data outlined above to determine relative changes of $P$. 
antipodarum and native invertebrate community abundance and biomass over the past ten years at each study location by comparing mean values across months and sample years. I will compare the mean numerical and biomass proportions of each invertebrate taxon for each sampling data set to determine whether these proportions could be used to investigate community structure over time. Bootstrap analyses will be used to test for differences between confidence intervals between years within re-sampled populations.

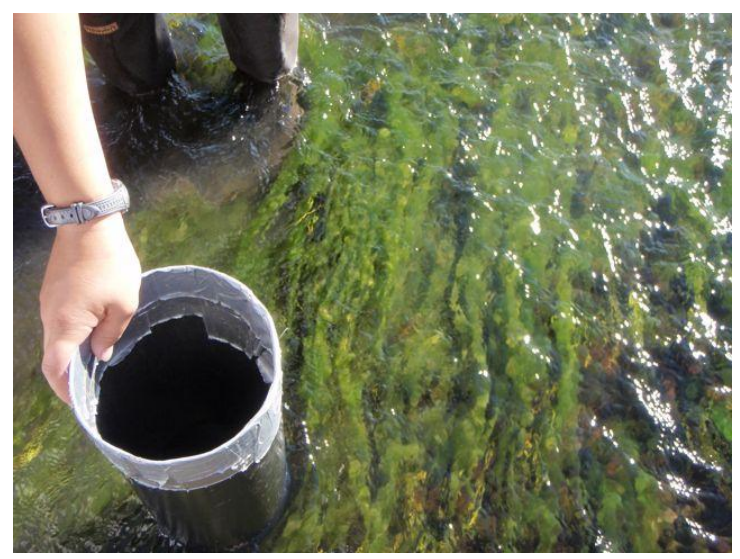

Figure 1. Stovepipe sampling device used to estimate macroinvertebrate biomass and abundance.

\section{$\downarrow \quad$ PRELIMINARY RESUltS}

All samples in the $>1-\mathrm{mm}$ size fraction have been picked from debris and separated into two subsample categories for measurement and identification: 1) mud snails and 2) all other invertebrates. Mud snails have been counted and measured in the samples for June and July at Polecat Creek. Mud snails have been counted and measured in three of the six samples at the Firehole River and all samples in the Gibbon River. Macroinvertebrates are in the process of being identified to the level of genus. Cataloging of specimens is in process at this time because all specimens have not been identified. Results are reported for the $>1-\mathrm{mm}$ size fractions only.

The mean abundance of mud snails in Polecat Creek for the > 1-mm size fraction was 9540 and 3583 individuals $/ \mathrm{m}^{2}$, for June and July respectively. In comparison, mean abundance of mud snails in the $>1-\mathrm{mm}$ size fraction sampled in June and July 2001 by Hall et al. (2006) were 42,400 and 121,550 individuals $/ \mathrm{m}^{2}$, respectively. The abundance of mud snails in the Gibbon River for the > 1-mm size fraction ranged from $0-100$ individuals $/ \mathrm{m}^{2}$, with three out of the six samples containing no mud snails and very few other macroinvertebrates. The abundance in the Firehole River for mud snails in the $>1-\mathrm{mm}$ size fraction ranged from 133 - 313 individuals $/ \mathrm{m}^{2}$. Mean abundance estimates of mud snails in August 2000 by Hall et al. (2006) were 7235 individuals $/ \mathrm{m}^{2}$ for the Gibbon River and 80,711 individuals $/ \mathrm{m}^{2}$ for the Firehole River. Data from recent macroinvertebrate samples indicate a $10-100$ fold decline in $P$. antipodarum abundance compared to surveys from 2001. Native macroinvertebrate species not found in 2001 were present in later samples, indicating changes in community assemblages.

These estimates support observational evidence from researchers over the past 5 years that mud snail abundance has decreased from previous levels. However, after preliminary analysis of data collected in 2011, it is clear that another year of study is necessary to better quantify a statistical difference in populations of $P$. antipodarum between years. The cool, wet summer and high flows may have affected the results of the survey in 2011, therefore the study will be continued in the summer of 2012 .

\section{MANAGEMENT IMPLICATIONS}

The proposed study serves to extend earlier assessments of changes within freshwater invertebrate assemblages that are imperative for understanding the long-term affects of $P$. antipodarum in the GYA. The results of this study are directly applicable to management of $P$. antipodarum with the GYA, and have potential consequences for understanding succession of this species in other regions. Considering the ecological and economic impact of invasive species at a global scale, understanding long-term affects of these species is vital for their long-term management.

\section{ACKNOWLEDGEMENTS}

I would like to thank field and laboratory assistants Jessica Liffrig and Sara Sheehan. Robert Hall, Amy Krist, Heather Thon and Mark Dybdahl have provided invaluable data, comments and support for the study.

\section{$\uparrow \quad$ LiTERATURE CITED}

Benke A.C, Huryn AD, Smock LA, Wallace, JB. 1999. Length-mass relationships for 
freshwater macroinvertebrates in North America with particular reference to the southeastern United States. Journal of the North American Benthological Society. 308343.

Dybdahl MF, Kane SL. 2005. Adaptation versus phenotypic plasticity in the success of an invasive snail. Ecology. 86(6): 1592 - 1601.

Hall RO Jr, Tank JL, Dybdahl MF. 2003. Exotic snails dominate nitrogen and carbon cycling in a highly productive stream. Frontiers in Ecology and the Environment. 1:407-411.

Hall RO, Dybdahl MF, VanderLoop MC. 2006. Invasive species and energy flow: extremely high secondary production of introduced snails in rivers. Ecological Applications. 16:1121-1131.

Heger T, Trepl L. 2003. "Predicting biological invasions." Biological Invasions. 5(4):313321.

Kerans BL, Dybdahl MF, Gangloff MM, Jannot JE. 2005. Potamopyrgus antipodarum: distribution, density, and effects on native macroinvertebrpate assemblages in the Greater Yellowstone Ecosystem. Journal of the North American Benthological Society 24:123-138.

Loo SE, Mac Nally R, Lake PS. 2007. Forecasting New Zealand mudsnail invasion range: model comparisons using native and invaded ranges. Ecological Applications. 17(1):181-189.
Mack RN, Simberloff D,Lonsdale WM, Evans H Clout M, Bazzaz, FA. 2000. Biotic invasions: causes, epidemiology, global consequences, and control. Ecological Applications. 10(3):689-710

Riley LA, Dybdahl MF, Hall RO. 2008. Invasive species impact: asymmetric interactions between invasive and endemic freshwater snails. Journal of the North American Benthological Society. 27:509-520.

Strayer DL. 2010. Alien species in fresh waters: ecological effects, interactions with other stressors, and prospects for the future. Freshwater Biology. 55:152-174, suppl. 1.

Schreiber ESG, Quinn GP, Lake PS. 2003. Distribution of an alien aquatic snail in relation to flow variability, human activities and water quality. Freshwater Biology. 48:951-961.

Zaranko DT, Farara DG, Thompson FG. 1997. Another exotic mollusk in the Laurentian Great Lakes: The New Zealand native Potamopyrgus antipodarum (Gray 1843) (Gastropoda, Hydrobiidae). Canadian Journal of Fish and Aquatic Science. 54:809-814. 